\title{
Public Sector Social-environmental Diagnosis Model: application in a federal autarky, Rio de Janeiro
}

\author{
Modelo de Diagnóstico Socioambiental para o Setor Público: \\ aplicação em uma autarquia federal - Rio de Janeiro/RJ

\begin{abstract}
Igor Laguna Vieira ${ }^{1}$ (1), Elmo Rodrigues da Silva ${ }^{1}$ (1), Ubirajara Aluizio de Oliveira Mattos ${ }^{1}$
${ }^{1}$ Universidade do Estado do Rio de Janeiro - UERJ, Programa de Pós-graduação em Engenharia Ambiental, Rio de Janeiro, RJ, Brasil. E-mail: igor_laguna@hotmail.com; elmorodrigues@yahoo.com.br; ubirajaraaluizio@yahoo.com.br
\end{abstract}

How to cite: Vieira, I. L., Silva, E. R., \& Mattos, U. A. O. (2020). Public Sector Social-environmental Diagnosis Model: application in a Federal Autarky, Rio de Janeiro. Gestão \& Produção, 27(3), e4957. https://doi.org/10.1590/0104-530X4957-20

\begin{abstract}
The Brazilian public administration system has thousands of organizations and departments at federal, state, and municipal levels, distributed throughout the national territory. These conduct activities that can have significant social and environmental impacts. The present research aims to propose a sustainability index through the Public Sector Social-environmental Diagnosis Model (DISASP). This model is based on the Environmental Management Accounting System developed by researchers from the Federal University of Santa Catarina. The proposed model complements this system by including the guidelines of the Environmental Public Administration Agenda, a Ministry of the Environment program that encourages socio-environmental management practices in the government sector. The DISASP method was tested in a federal autarky in the city of Rio de Janeiro. For institutional diagnosis, seven managers were sent a questionnaire containing 124 questions with eight thematic axes: Rational Use of Natural Resources and Public Goods; Adequate Waste Management; Quality of Life in the Work Environment; Awareness and Training; Sustainable Public Procurement; Sustainable Construction; Social and Environmental Responsibility; and Institutional Management. A "weak" sustainability index was obtained, indicating the need for this sector to improve its socio-environmental performance. The study indicated that DISASP adequately fulfilled its role as an instrument for assessing socio-environmental practices in the public sector. Future studies should extend application of the DISASP method to the autarky under study at various points in time, as well as apply it to other public agencies.
\end{abstract}

Keywords: Environmental Management Accounting System; Public Sector Social-environmental Diagnosis Model; Environmental Agenda in Public Administration; Social and Environmental Assessment; Social and Environmental Sustainability.

Resumo: A administração pública brasileira possui milhares de órgãos e setores distribuídos pelo território nacional, em nível federal, estadual e municipal, desenvolvendo atividades que podem provocar impactos sociais e ambientais significativos. O objetivo desta pesquisa é propor um índice de sustentabilidade por meio do Modelo de Diagnóstico Socioambiental para o Setor Público (Disasp). Esse modelo baseia-se no Sistema Contábil Gerencial Ambiental, elaborado por pesquisadores da Universidade Federal de Santa Catarina. O modelo proposto complementa esse sistema incluindo as diretrizes da Agenda Ambiental da Administração Pública, programa

Received July 27, 2018 - Accepted Dec. 7, 2018.

Financial support: None.

This is an Open Access article distributed under the terms of the Creative Commons Attribution License, which permits unrestricted use, distribution, and reproduction in any medium, provided the original work is properly cited. 
do Ministério do Meio Ambiente que busca incentivar práticas de gestão socioambiental no setor governamental. O método Disasp foi testado em uma autarquia federal situada no município do Rio de Janeiro. Para o diagnóstico da instituição direcionou-se o questionário a sete gestores, contendo 124 questões, segundo oito eixos temáticos: Uso Racional dos Recursos Naturais e Bens Públicos; Gestão Adequada dos Resíduos; Qualidade de Vida no Ambiente de Trabalho; Sensibilização e Capacitação; Compras Públicas Sustentáveis; Construções Sustentáveis; Responsabilidade Socioambiental; e Gestão Institucional. Como resultado, obteve-se um índice de sustentabilidade considerado "fraco", indicando a necessidade de esse órgão melhorar seu desempenho socioambiental. O estudo indica que o Disasp cumpriu de forma adequada seu papel como instrumento de avaliação socioambiental para o setor público. Para estudos futuros, pode-se estender a aplicação do método Disasp em outros momentos da autarquia estudada, bem como aplicá-lo a outros órgãos públicos.

Palavras-chave: Sistema Contábil Gerencial Ambiental; Diagnóstico Socioambiental do Setor Público; Agenda Ambiental na Administração Pública; Avaliação Socioambiental; Sustentabilidade Socioambiental.

\section{Introduction}

Organizations, whether public or private, play an important role in the pursuit of social and environmental sustainability. Some companies are able to take better advantage of their resources by adopting environmental management as a competitive advantage, avoiding waste and employing more advanced technologies. Such companies must comply with environmental legislation to reduce the risk of environmental penalties or liabilities (Tauchen \& Brandli, 2006).

According to Guthrie \& Parker (1989), organizations are legitimized by their operation in society through a social contract. In light of the theory of legitimacy, managers play a fundamental role in perceiving how the organization is seen by society. Organizational practices may break with this social contract in some ways, for example with respect to the environment, citizenship, customs, and legal order, and it is necessary that corrective strategies be disclosed, changing society's perception of the organization (Deegan, 2002, Conceição et al., 2011).

Some government programs and projects have been proposed to encourage public managers to adopt practices stimulating socio-environmental responsibility in their spheres (federal, state, and municipal), including adopting responsible practices as part of their long-term sustainability strategy (Souza et al., 2017). The Environmental Public Administration Agenda (A3P), for example, was created in 2001 by the Ministry of the Environment, aiming to encourage more responsible socio-environmental management in public agencies in general (Brasil, 2009).

Actions that positively or negatively impact the environment ultimately reflect the organization's image in society. To evaluate these impacts, various tools and methods have been developed, including the Model for Environmental Assessment in Industrial Production Systems (MAASPI) (Silva \& Amaral, 2011), the Economic Model of Control and Evaluation of Environmental Impacts (MECAIA) (Kraemer, 2002), and the Methodology for Assessment of Environmental Impacts and Costs in Industrial Processes (MAICAPI) (Silva \& Amaral, 2006, 2009).

Considering the importance of measuring what one wants to manage, these organizational sustainability evaluation tools help managers to define the course of their actions in favor of sustainable development. The tools also allow stakeholders to be informed of how the organization deals with the sustainability tripod-in other words, how it considers the economic, environmental, and social dimensions of sustainable 
development (Elkington, 1997; Teles et al., 2016). There is an apparent consensus in the scientific literature regarding the utility of these tools (Scholl et al., 2015). However, putting them into practice can be challenging. Scientific knowledge regarding the disruption of terrestrial ecosystems by organizational activities is still incipient and therefore often uses estimates, which, because they contain subjectivities, are the subject of controversy and debate (Di Agustini \& Giannetti, 2018).

Highlighted among the evaluation instruments identified in the specific context of this research is the Environmental Management Accounting System (SICOGEA) developed by Pfitscher (2004) at the Federal University of Santa Catarina, based on the Environmental Aspects and Impacts Management (GAIA) method developed by Lerípio (2001) at the same institution. In 2010, SICOGEA was structurally modified, giving rise to Generation 2 (Nunes, 2010).

Goldstein et al. (2011) indicate that sustainability assessment should be conducted in a sector-specific way. Notably, none of the environmental diagnosis models mentioned above were developed specifically for application in government agencies, illustrating the importance of developing a method to fill this gap.

This work proposes a method for evaluating the socio-environmental sustainability of public administrations, called the Public Sector Socio-Environmental Diagnostic Model (DISASP), which was tested at an autarky located in the city of Rio de Janeiro.

Methodologically, this study takes a qualitative and descriptive approach. The objective of descriptive research is to portray the characteristics of a given population or phenomenon, or to establish relationships between variables. It involves standardized techniques of data collection, such as questionnaires and systematic observation, and usually takes the form of a survey (Gil, 2017).

The SICOGEA (Generation 2) method was used as the basis for the proposed public sector socio-environmental sustainability index, with some adaptations, such as inclusion of suggested proposals in A3P reference documents (Brasil, 2009, 2015).

This study's motivation is the fact that society demands transparency from organizations, especially governmental organizations, meaning they must evaluate the effectiveness of their contribution to sustainable development.

This article is organized in five sections. This remainder if this introduction contains two subsections that address A3P and the SICOGEA method, respectively. Section 2 presents the proposal for the DISASP method. Section 3 reports the results of practical application of the model in a federal autarky located in Rio de Janeiro/RJ. Section 4 discusses the implications of DISASP. Finally, section 5 presents the final considerations of the paper.

\subsection{Environmental Agenda in Public Administration (A3P)}

The A3P has 15 (fifteen) basic objectives, namely: I - To support public agencies in creating and implementing social and environmental responsibility actions; II - To sensitize public servants to the need to preserve natural assets; III - To stimulate construction of an institutional culture with values, attitudes, and behaviors consonant with socioenvironmental responsibility; IV - To encourage public agencies to adopt measures to reduce the negative socio-environmental impacts of their activities; $V$ - To increase management efficiency, promoting the conservation of natural resources and institutional expenditures; $\mathrm{VI}$ - To promote systematic updating of knowledge and modernization of concepts, instruments, technologies and methodologies with respect to the field of sustainability; VII - To promote transparency in public service; VIII - To ensure accessibility 
to public agencies for individuals with disabilities or reduced mobility; IX - To stimulate and support actions to defend the environment; $X$ - To facilitate access to the A3P program for public institutions; XI - To encourage cooperation, solidarity, respect, and professional and ethical commitment in institutional actions; XII - To train and sensitize public managers regarding socio-environmental responsibility; XIII - To collaborate to improve the quality of life of public servants; XIV - To encourage collective action and democratic decisions; and XV - To promote sustainable production and consumption (Brasil, 2018).

To achieve its objectives, the A3P was organized into six thematic axes, shown in Table 1, which contain its fundamental aspects.

Table 1. A3P Thematic Axes.

\begin{tabular}{|c|c|}
\hline Thematic Axes & Fundamentals \\
\hline $\begin{array}{l}\text { Rational Use of Natural } \\
\text { Resources and Public } \\
\text { Goods }\end{array}$ & $\begin{array}{c}\text { Rational use of natural resources and public goods means avoiding } \\
\text { wasteful use. This axis involves the rational use of energy, water, and } \\
\text { wood, as well as consumption of raw materials, such as paper, } \\
\text { plastic cups, and others. }\end{array}$ \\
\hline $\begin{array}{l}\text { Adequate Management } \\
\text { of Generated Waste }\end{array}$ & $\begin{array}{l}\text { Proper waste management is pursued through adoption of the } 5 \text { R's } \\
\text { policy: Refuse, Reduce, Reuse, Repurpose, and Recycle. Priority } \\
\text { should be given to reducing consumption and combatting waste, not } \\
\text { only to properly handling the waste generated. }\end{array}$ \\
\hline $\begin{array}{l}\text { Quality of Life in the } \\
\text { Work Environment }\end{array}$ & $\begin{array}{l}\text { This axis seeks to facilitate and satisfy the needs of workers through } \\
\text { actions aimed at personal and professional development. }\end{array}$ \\
\hline Awareness and Training & $\begin{array}{l}\text { Awareness-raising aims to establish the socio-environmental } \\
\text { responsibility of public workers. Training seeks to facilitate } \\
\text { development of institutional and individual competencies, so that } \\
\text { employees develop attitudes aimed at improving their activities. }\end{array}$ \\
\hline $\begin{array}{l}\text { Sustainable Public } \\
\text { Procurement }\end{array}$ & $\begin{array}{l}\text { Public administration must pursue social and environmental } \\
\text { responsibility in its purchases. Sustainable purchases are important } \\
\text { for environmental preservation and have a better cost-benefit ratio in } \\
\text { the medium- or long-term compared to purchases based only on the } \\
\text { lowest price. }\end{array}$ \\
\hline $\begin{array}{l}\text { Sustainable } \\
\text { Construction }\end{array}$ & $\begin{array}{l}\text { Sustainable construction refers to a set of measures adopted during } \\
\text { all stages of a project for the sustainability of the building. Adopting } \\
\text { these measures can minimize negative environmental impacts, } \\
\text { promote the economy of natural resources, and improve the quality of } \\
\text { life of the building's occupants. }\end{array}$ \\
\hline
\end{tabular}

Source: Adapted from Brasil (2009, 2019a).

Mobilizing and sensitizing public servants is crucial if A3P is to be effectively implemented. It is also necessary to plan and monitor actions using performance indicators, which are considered fundamental tools to support managers (Di Agustini \& Giannetti, 2018). Environmentally appropriate activities should be encouraged, such as implementing selective collection of recyclable waste, reducing consumption of water and other natural resources, replacing disposable cups with reusable alternatives, and using more efficient electronic devices, among others.

This agenda proposes a multiplier and renewal result based on environmental education to change the culture and habits of public servants, helping to improve the 
image of public administration in response to society's disapproval of the sector's exaggeration of expenses and lack of transparency (Lima, 2015).

\subsection{Environmental Management Accounting System (SICOGEA)}

SICOGEA can be defined as an environmental management tool that connects accounting to the environment through controls, aiming to "[...] generate information for the manager about the impacts of their actions on the environment, with the aid of environmental accounting and control [...]" (Nunes, 2010, p. 63).

Using the SICOGEA method, an organization can contribute to environmental sustainability by evaluating the environmental aspects and associated impacts of its activities. Because environmental accounting is included in the system, it is also possible to obtain economic and social-environmental benefits, such as reduction of waste and expenses, and to improve pollution control and prevention (Pfitscher, 2004). The tool's creator sought collaboration with various universities and research centers to improve it for public use.

Nunes (2010) proposed adaptations and improvements to SICOGEA, resulting in Generation 2 of the method. The main suggestions included changing the structure of the checklist, dividing the list by key groups and subgroups, including key issues in the list items, using a 0 to 5 scale for responses, assigning different points to each issue at the discretion of the analyst, including a weighting worksheet, changing the structure of indicators, including two formulas to identify the efficiency indexes of the items, and using the $5 \mathrm{~W} 2 \mathrm{H}$ structure for future applications (5W: Who, What, Where, When, and Why; $2 \mathrm{H}$ : How and How Much). For the general sustainability index, values vary from $0 \%$ to $100 \%$ (Nunes, 2010). The changes are summarized in Table 2.

Table 2. Evolution of Sustainability Assessment in SICOGEA.

\begin{tabular}{|c|c|c|}
\hline Attributes & SICOGEA & SICOGEA (Generation 2) \\
\hline $\begin{array}{l}\text { Scale for measuring checklist } \\
\text { responses }\end{array}$ & $\begin{array}{c}3 \text { levels: Adequate - A; Deficit - } \\
\text { D; Not applicable - NA }\end{array}$ & $\begin{array}{c}6 \text { levels: } 0 \text { to } 5 \text { and NA - Not } \\
\text { applicable }\end{array}$ \\
\hline General index of sustainability & $\begin{array}{c}\text { (Total issues rated } A \times 100) / \\
\text { (Total questions }- \text { total issues } \\
\text { rated NA) }\end{array}$ & $\begin{array}{l}\text { (Possible points) / (Points } \\
\text { achieved) }\end{array}$ \\
\hline $\begin{array}{c}\text { Environmental sustainability } \\
\text { assessment }\end{array}$ & $\begin{array}{c}\quad \leq 50 \% \text { - Deficit } \\
51 \%-70 \% \text { - Normal } \\
\geq 71 \% \text { - Appropriate }\end{array}$ & $\begin{array}{c}\leq 20 \% \text { - Poor } \\
21 \%-40 \% \text { - Weak } \\
41 \%-60 \% \text { - Normal } \\
61 \%-80 \% \text { - Good } \\
>80 \% \text { - Excellent }\end{array}$ \\
\hline $\begin{array}{c}\text { Option to assign weight to } \\
\text { questions }\end{array}$ & No & Yes \\
\hline
\end{tabular}

Source: Adapted from Pfitscher (2004) and Nunes (2010).

\subsubsection{Applications of SICOGEA in public agencies}

A federal autarky located in Rio de Janeiro was evaluated by Vieira et al. (2018) using the SICOGEA method (Generation 2). The administrative body achieved a "regular" level of sustainability. Because the autarky is a public agency, the researchers suggested assigning a weight of two to the issues directly linked to the six thematic 
axes of A3P when applying the SICOGEA questions to obtain a diagnosis. All other issues were assigned a weight of one.

SICOGEA has also been applied to other public agencies. Souza \& Pfitscher (2013) used the method to analyze sustainability in the agency responsible for controlling the application of public resources in the state and the municipalities of Santa Catarina, obtaining a result of "regular." Barbosa (2014) assessed the sustainability of the Federal Justice of the Amazon, also obtaining a diagnosis of "regular." All the researchers cited supported the need to adjust the system to make it fully applicable to the public sector.

Kruger et al. (2013) evaluated the environmental sustainability of a higher education institution in Santa Catarina, obtaining the result of "good." The authors emphasized the need to complement SICOGEA with other measures for application in public agencies, even suggesting $\mathrm{A} 3 \mathrm{P}$ as a possible basis.

Other studies also used SICOGEA to evaluate public education institutions. Freitas et al. (2016) verified accessibility for academics with some type of disability or reduced mobility in a teaching center of the Federal University of Santa Catarina, also adapting the original model, and obtained a result of "regular." Rocha et al. (2015) adapted SICOGEA to evaluate a public higher education institution and obtained a result of "weak."

Souza et al. (2015) analyzed the environmental sustainability of a higher education institution in Santa Catarina using SICOGEA, obtaining a result of "weak." It should be emphasized that the study also investigated the target institution's adherence to the A3P axes. Similar to Vieira \& Silva (2018) and Vieira et al. (2018), these authors obtained a considerable difference in score when using SICOGEA and when analyzing adherence to the A3P axes. Souza et al. (2015) explained that this was because A3P was developed exclusively for government agencies, and thus covers the points most relevant to such bodies. SICOGEA is more generic, and can be applied to both public and private institutions.

\section{Development of the Public Sector Social-environmental Diagnosis Model (DISASP)}

DISASP was developed by including A3P propositions (Brasil, 2009, 2015) in the SICOGEA model (Generation 2) proposed by Nunes (2010). Only those questions assigned a weight of two by Vieira et al. (2018) were included from the SICOGEA method (Generation 2). The sustainability index proposed in DISASP was conceived based on the awareness of an important gap to be filled with a method considering the specificities of the public sector. This was evidenced in Vieira et al. (2018) application of the SICOGEA method to evaluate a federal autarky located in Rio de Janeiro, which identified points relevant to the public sector that were not considered by SICOGEA (such as public procurement and contracting through a bidding process).

SICOGEA (Generation 2) uses a scale from 0 to 5 to score questions. In the present research, a smaller scale was chosen for DISASP ( 0 to 2$)$ than was used by Vieira et al. (2018), as shown in Table 3. However, it is important to note a significant difference exists between the two variables. In applying the DISASP sustainability index, we sought to reduce subjectivity in respondents' answers, eliminating the attribution of weights to the and avoiding prioritization of one theme over another. 
Table 3. Evolution of Sustainability Assessment, SICOGEA vs. DISASP.

\begin{tabular}{|c|c|c|}
\hline Items & SICOGEA (Generation 2) & DISASP \\
\hline $\begin{array}{l}\text { Scale for measuring } \\
\text { checklist responses }\end{array}$ & $\begin{array}{c}6 \text { levels: } 0 \text { to } 5 \text { and NA - Not } \\
\text { applicable }\end{array}$ & $\begin{array}{c}3 \text { levels: } 0 \text { to } 2 \text { and NA - not } \\
\text { applicable }\end{array}$ \\
\hline $\begin{array}{l}\text { General index of } \\
\text { sustainability }\end{array}$ & $\begin{array}{c}\text { (Possible points) / (Points } \\
\text { achieved) }\end{array}$ & (Possible points) / (Points achieved) \\
\hline Areas/axes evaluated & $\begin{array}{c}\text { - Production } \\
\text { - Human Resources } \\
\text { - Marketing } \\
\text { - Finance }\end{array}$ & $\begin{array}{c}\text { - Rational Use of Natural } \\
\text { Resources and Public Goods } \\
\text { - Adequate Management of } \\
\text { Generated Waste } \\
\text { - Quality of Life in the Work } \\
\text { Environment } \\
\text { - Awareness and Training } \\
\text { - Sustainable Public Procurement } \\
\text { - Sustainable Construction } \\
\text { - Social and Environmental } \\
\text { Responsibility } \\
\text { - Institutional Management }\end{array}$ \\
\hline $\begin{array}{l}\text { Environmental } \\
\text { sustainability } \\
\text { assessment }\end{array}$ & $\begin{array}{c}\leq 20 \% \text { - Poor } \\
21 \%-40 \% \text { - Weak } \\
41 \%-60 \% \text { - Regular } \\
61 \%-80 \% \text { - Good } \\
>80 \% \text { - Excellent }\end{array}$ & $\begin{array}{c}\leq 20 \% \text { - Poor } \\
21 \%-40 \% \text { - Weak } \\
41 \%-60 \% \text { - Regular } \\
61 \%-80 \% \text { - Good } \\
>80 \% \text { - Excellent }\end{array}$ \\
\hline $\begin{array}{l}\text { Option to assign weight } \\
\text { to questions }\end{array}$ & Yes & No \\
\hline
\end{tabular}

The nomenclature of the DISASP axes follows that of A3P (Table 1). To provide a more complete sustainability assessment, two new axes were suggested: "Social and Environmental Responsibility" and "Institutional Management." Questions were reproduced from SICOGEA for each thematic axis, including only those with relevance to the public sector. The questionnaire was complemented by questions related to good sustainability practices proposed by A3P. The two new axes were included because not all the SICOGEA questions fit the thematic axes proposed by A3P.

For DISASP, 124 issues were proposed in the following thematic axes: Rational Use of Natural Resources and Public Goods (28 questions); Adequate Management of Generated Waste (11 questions); Quality of Life in the Work Environment (24 questions); Awareness and Training (8 questions); Sustainable Public Procurement (15 questions); Sustainable Construction (11 questions); Social and Environmental Responsibility (11 questions); and Institutional Management (16 questions).

Each question was assessed according to the proposed scale, as follows:

0 - no compliance shown

1 - partial compliance shown

2 - full compliance shown

The evaluation results developed by Nunes (2010) were adopted, shown in Table 3 under Environmental Sustainability Assessment.

After application of DISASP, organizations should propose Action Plans, an example of which is presented in Table 4, in addition using a set of indicators to monitor and follow management after implementing environmental improvements, preferably those recommended by A3P (Brasil, 2019b). 
Table 4. Example Action Plan.

\begin{tabular}{ccccc}
\hline \multicolumn{5}{c}{ Action Plan } \\
\hline Theme & \multicolumn{1}{c}{ Goals } & Responsibility & Start & Conclusion \\
\hline \multirow{2}{*}{ Water } & $\begin{array}{c}\text { Conduct automated monitoring of } \\
\text { water consumption. }\end{array}$ & Engineering & 2018 & - \\
\cline { 2 - 5 } & $\begin{array}{c}\text { Promote awareness campaigns to } \\
\text { reduce water consumption. }\end{array}$ & $\begin{array}{c}\text { Institutional } \\
\text { management }\end{array}$ & 2018 & - \\
\hline
\end{tabular}

The method proposed here is indicated only for public agencies without a great environmental impact potential. Therefore, it is not intended for institutions with laboratories and operating rooms, for example, as such sites involve high-risk activities and present environmental aspects that are more relevant from the perspective of the associated impacts.

\section{Results}

The sustainability index used in DISASP was applied to the same municipality analyzed by Vieira et al. (2018); answers to the questionnaires are presented in Appendix A.

The target federal autarky is located in the city of Rio de Janeiro. It has two buildings located on the same street, comprising a total built area of 9,000 square meters accommodating approximately 500 employees. Only administrative activities typical of the public sector are conducted at the organization's headquarters. The results of the DISASP application in this municipality are shown in Table 5.

Table 5. DISASP application results.

\begin{tabular}{ccccc}
\hline Axes & Possible & $\begin{array}{c}\text { Points } \\
\text { Achieved }\end{array}$ & \multicolumn{2}{c}{ Sustainability Level } \\
\cline { 5 - 5 } & Points & Result & Evaluation \\
\hline $\begin{array}{c}\text { Rational Use of Natural Resources } \\
\text { and Public Goods }\end{array}$ & 54 & 13 & $24 \%$ & Weak \\
\hline $\begin{array}{c}\text { Adequate Management of Generated } \\
\text { Waste }\end{array}$ & 22 & 04 & $18 \%$ & Poor \\
\hline $\begin{array}{c}\text { Quality of Life in the Work } \\
\text { Environment }\end{array}$ & 48 & 17 & $35 \%$ & Weak \\
\hline $\begin{array}{c}\text { Awareness and Training } \\
\text { Sustainable Public Procurement }\end{array}$ & 16 & 04 & $25 \%$ & Weak \\
\hline $\begin{array}{c}\text { Sustainable Construction } \\
\text { Social and Environmental } \\
\text { Responsibility }\end{array}$ & 22 & 11 & $37 \%$ & Weak \\
\hline $\begin{array}{c}\text { Institutional Management } \\
\text { Total }\end{array}$ & 20 & 07 & $32 \%$ & Weak \\
\hline & $\mathbf{2 4 4}$ & 10 & $31 \%$ & Weak \\
\hline
\end{tabular}

After applying the method, the sustainability level of the analyzed municipality was evaluated as "Weak" overall, and received an evaluation of "Poor" for the axes of Adequate Management of Generated Waste and Social and Environmental Responsibility. The autarky did not selectively collect recyclable waste, environmental themes were not prioritized within the institution, and no specific policy was developed to address this issue, all of which contributed strongly to the results shown. 
The results showed the need for actions to improve the autarky's socio-environmental sustainability, such as implementing a selective collection program in compliance with Decree 5.940/2006, which obligated "[...] separating recyclable waste discarded by organs and entities of the federal direct and indirect public administration, at the generating source, and their destination, to the associations and cooperatives of the collectors of recyclable materials" (Brasil, 2006, preamble). Immediate formation of a commission for this purpose and contact with cooperatives and associations to collect recyclable waste is advisable.

It is also necessary for the organization to improve its preservation and socialenvironmental actions, including better communication with society. This would benefit the organization's image with respect to public opinion, which would value its relationship with the environment.

\section{Discussion}

DISASP enables public organizations to measure and evaluate their contributions to sustainable development. Ideally, the results of its application should be widely disseminated to society, in keeping with Teles et al. (2016), who state that sustainability assessment instruments can serve as tools for social and environmental disclosure. Lima (2015) also notes the importance of changing society's perspective of public spending and transparency, legitimizing the actions of the public power government. Outreach strategies can reverse or soften a negative image of an organization among its stakeholders. Therefore, it is crucial to highlight and project a positive organizational image by correctly using legitimacy strategies (Guthrie \& Parker, 1989; Deegan, 2002; Conceição et al., 2011).

The method of assessing socio-environmental sustainability proposed by DISASP, a tool geared toward the governmental sector that considers the specificities of public administration, can be applied by managers in decision making, as suggested by Goldstein et al. (2011).

It should be noted that the public power has a responsibility regarding issues relevant to society; the results of this study show that the target autarky must reinforce its actions for socio-environmental sustainability. This autarky had already been submitted to two previous evaluation methods: SICOGEA (Vieira et al., 2018) and A3P (Vieira \& Silva, 2018). The first resulted in an assessment of "regular"; the second resulted in an assessment of "weak."

DISASP was conceived after the managers of the target autarky expressed difficulties in responding to the SICOGEA questionnaire using the numerical scale ranging from 0 to 5, based on the proposals of Nunes (2010). Respondents considered the scale too broad to evaluate qualitative issues. Therefore, a smaller scale (ranging from 0 to 2) was chosen for the items comprising DISASP. An additional difficulty was SICOGEA's inclusion of questions not fully applicable to the public sector; questions were needed concerning good sustainability practices in government agencies, as suggested by A3P (Brasil, 2009, 2015). Consequently, the managers of the target municipality considered DISASP more effective in assessing socio-environmental issues in public agencies. Finally, SICOGEA is the fact that the researcher attributes weight to the questions formulated. DISASP suggests that all issues have the same importance, making no sense to assign different weights to them.

Previous applications of SICOGEA in public agencies showed that adaptations to the system were required to apply it to the government sector (Kruger et al., 2013; Souza \& Pfitscher, 2013; Barbosa, 2014; Rocha et al., 2015; Souza et al., 2015; 
Freitas et al., 2016). Because DISASP is intended for use as a standard tool for the public sector, the sustainability index proposed requires no adaptation. The tool focuses on issues of high relevance to sustainability in the public sector, in line with Goldstein et al. (2011) assertion that sustainability assessment must be sector-specific.

\section{Final considerations and suggestions for future research}

Discussions of sustainable development have been gaining increasing weight in society. Public administration must be aware of this reality and propose programs and policies to stimulate the principles of socio-environmental responsibility within the sector.

Given this background, the present research aimed to present a socio-environmental diagnosis model for the public sector. Adaptation of and improvements to the SICOGEA questionnaire were proposed, altering its scale of evaluation. The questionnaire was complemented by practices and thematic axes from the A3P, ultimately resulting in development of the Public Sector Social-environmental Diagnosis Model (DISASP). This tool is intended to facilitate development of Social and Environmental Management Plans in public sector agencies. Furthermore, a sustainability assessment method that considers the specificities of the public sector fills an important gap in the literature.

Application of DISASP in a federal autarky resulted in a sustainability assessment of "weak," indicating the necessity of to improve the organization's social and environmental sustainability.

This study indicates that the proposed method adequately performed its role as a social and environmental assessment tool for the public sector. It identified the failures and successes of the target agency and was praised by the managers participating in the research for the objectivity of its questions, aimed specifically at this sector.

A limitation of this method is that it applies only to public agencies without a significant environmental impact potential. Additionally, the consistency of the data analysis depends on the commitment of the questionnaire respondents to portray the reality of the agency.

Future research should monitor the development of sustainability in the target autarky by applying the DISASP method at other times. It should also be applied in other public agencies, both to improve this tool and so that the agencies can better understand their strengths, weaknesses, threats, and opportunities concerning sustainability. It is recommended that such assessments be widely disseminated to society in the form of sustainability reports.

\section{References}

Barbosa, N. M. (2014). Análise da sustentabilidade ambiental na justiça federal do Amazonas: estudo de caso usando um sistema contábil gerencial ambiental (Dissertação de mestrado). Universidade Federal do Amazonas, Manaus.

Brasil. (2006, 26 de outubro). Decreto $n^{\circ}$ 5.940, de 25 de Outubro de 2006. Institui a separação dos resíduos recicláveis descartados pelos órgãos e entidades da administração pública federal direta e indireta, na fonte geradora, e a sua destinação às associações e cooperativas dos catadores de materiais recicláveis, e dá outras providências (seção 1, nº 206, pp. 4). Brasília, DF: Diário Oficial da República Federativa do Brasil.

Brasil. (2009). Agenda Ambiental na Administração Pública (5. ed.). Brasilia: Ministério do Meio Ambiente. 
Brasil. (2015). Como implantar a A3P (2. ed.). Brasilia: Ministério do Meio Ambiente.

Brasil. (2018, 27 de fevereiro). Portaria $n^{\circ}$ 3, de 27 de Fevereiro de 2018. Institui as diretrizes do Programa da Agenda Ambiental na Administração Pública - Programa A3P (seção 1, no 41, pp. 65). Brasília, DF: Diário Oficial da República Federativa do Brasil.

Brasil. (2019a). Construções sustentáveis. Brasilia: Ministério do Meio Ambiente. Retrieved in 2019, February 24, from http://www.mma.gov.br/component/k2/item/10317-thematicrights-sustainablebuildings

Brasil. (2019b). Indicadores de desempenho da A3P. Brasilia: Ministério do Meio Ambiente. Retrieved in 2019, February 24, from http://www.mma.gov.br/images/arquivo/80063/Indicadores\%20da\%20A3Pversao\%20final.pdf

Conceição, S. H., Dourado, G. B., Baqueiro, A. G., Freire, S., \& Brito, P. C. (2011). Communication level and determinant factors of corporative social responsibility disclosure: a qualitative and quantitative study of companies listed in Bovespa. Gestão \& Produção, 18(3), 461-472. http://dx.doi.org/10.1590/S0104-530X2011000300002.

Deegan, C. (2002). Introduction: the legitimising effect of social and environmental disclosures - a theoretical foundation. Accounting, Auditing \& Accountability Journal, 15(3), 282-311. http://dx.doi.org/10.1108/09513570210435852.

Di Agustini, C. A., \& Giannetti, B. F. (2018). Assessment of environmental sustainability indexes of water supply and sewage treatment companies listed on the BM\&FBOVESPA. Gestão \& Produção, 25(4), 1-15. http://dx.doi.org/10.1590/0104-530x3459-17.

Elkington, J. (1997). Cannibals with forks: the triple bottom line of 21st century business. Oxford: Capstone.

Freitas, K. E., Pfitscher, E. D., \& Belan, A. B. (2016). Accessibility analysis: application of partial Sicogea model in a training center of a federal institution of education. Revista de Gestão Ambiental e Sustentabilidade, 5(3), 120-134. http://dx.doi.org/10.5585/geas.v5i3.394.

Gil, A. C. (2017). Como elaborar projetos de pesquisa (6. ed.). Sao Paulo: Atlas.

Goldstein, D., Hilliard, R., \& Parker, V. (2011). Environmental performance and practice across sectors: methodology and preliminary results. Journal of Cleaner Production, 19(9-10), 946-957. http://dx.doi.org/10.1016/j.jclepro.2010.12.012.

Guthrie, J., \& Parker, L. D. (1989). Corporate social reporting: a rebuttal of legitimacy theory. Accounting and Business Research, 19(76), 343-352. http://dx.doi.org/10.1080/00014788.1989.9728863.

Kraemer, T. H. (2002). Modelo econômico de controle e avaliação de impactos ambientais (Tese de doutorado). Universidade Federal de Santa Catarina, Florianópolis.

Kruger, S., Pfitscher, E. D., Uhlmann, V. O., \& Petri, S. M. (2013). Environmental sustainability: study in an institution of learning catarinense. Sociedade, Contabilidade e Gestão, 8(1), 98112. http://dx.doi.org/10.21446/scg_ufrj.v8i1.13285.

Lerípio, A. A. (2001). GAIA: um método de gerenciamento de aspectos e impactos ambientais (Tese de doutorado). Universidade Federal de Santa Catarina, Florianópolis.

Lima, M. A. (2015). Does public administration sustain itself? Desenvolvimento e Meio Ambiente, 34, 191-194. http://dx.doi.org/10.5380/dma.v34i0.38570.

Nunes, J. P. O. (2010). Um aporte ao sistema contábil gerencial ambiental: elaboração e aplicação parcial do novo sistema em clínica hospitalar (Dissertação de mestrado). Universidade Federal de Santa Catarina, Florianópolis.

Pfitscher, E. D. (2004). Gestão e sustentabilidade através da contabilidade e controladoria ambiental: estudo de caso na cadeia produtiva de arroz ecológico (Tese de doutorado). Universidade Federal de Santa Catarina, Florianópolis. 
Rocha, S., Pfitscher, E., \& Carvalho, F. (2015). Sustentabilidade ambiental: estudo em uma instituição de ensino superior pública catarinense. Revista de Gestão Ambiental e Sustentabilidade, 4(1), 46-58. http://dx.doi.org/10.5585/geas.v4i1.162.

Scholl, C. A., Hourneaux, F., Jr., \& Galleli, B. (2015). Sustentabilidade organizacional: aplicação de índice composto em uma empresa do setor químico. Gestão \& Produção, 22(4), 695-710. http://dx.doi.org/10.1590/0104-530X1343-13.

Silva, P. R. S., \& Amaral, F. G. (2006). Methodology for assessment of environmental impacts and costs in industrial processes: a case study. Revista de Engenharia Sanitária e Ambiental, 11(3), 212-222. http://dx.doi.org/10.1590/S1413-41522006000300004.

Silva, P. R. S., \& Amaral, F. G. (2009). An integrated methodology for environmental impacts and costs evaluation in industrial processes. Journal of Cleaner Production, 17(15), 13391350. http://dx.doi.org/10.1016/j.jclepro.2009.04.010.

Silva, P. R. S., \& Amaral, F. G. (2011). Model for Environmental Assessment in Industrial Production Systems: a case study in a company that manufactures metallic structures. Gestão \& Produção, 18(1), 41-54. http://dx.doi.org/10.1590/S0104-530X2011000100004.

Souza, L. D., Valadão, V. M., Jr., \& Medeiros, C. R. O. (2017). Crime corporativo e o discurso da responsabilidade socioambiental: inconsistências, contradições e indiferença no diálogo da corporação com stakeholders. Gestão \& Produção, 24(4), 690-703. http://dx.doi.org/10.1590/0104-530x1394-17.

Souza, P., \& Pfitscher, E. D. (2013). Environmental management and sustainability: a study in a public agency of the state of Santa Catarina. Revista de Contabilidade e Controladoria, 5(3), 8-32. http://dx.doi.org/10.5380/rcc.v5i3.30134.

Souza V. D., Uhlmann V. O., \& Pfitscher, E. D. (2015). Environmental sustainability in educational institution: adherence to the Environmental Agenda of Public Administration. Perspectivas Contemporâneas, 10(1), 126-145.

Tauchen, J. A., \& Brandli, L. L. (2006). A gestão ambiental em instituições de ensino superior: modelo para implantação em campus universitário. Gestão \& Produção, 13(3), 503-515. http://dx.doi.org/10.1590/S0104-530X2006000300012.

Teles, C. D., Dutra, C. C., Ribeiro, J. L. D., \& Guimarães, L. B. M. (2016). Uma proposta para avaliação da sustentabilidade socioambiental utilizando suporte analítico e gráfico. Production, 26(2), 417-429. http://dx.doi.org/10.1590/0103-6513.0638T6.

Vieira, I. L., \& Silva, E. R. (2018). Analysis of the adherence of a federal autarky to A3P axes Rio de Janeiro/RJ. In Proceedings of the XI Congresso Internacional de Tecnologia para o Meio Ambiente (pp. 1-8). Bento Gonçalves: FIEMA.

Vieira, I. L., Silva, E. R., \& Pfitscher, E. D. (2018). Evaluation of the environmental sustainability of the administrative office of a federal institution - Rio de Janeiro, Brazil. Revista Internacional de Ciências, 8(2), 209-224. http://dx.doi.org/10.12957/ric.2018.33255. 
Appendix A. DISASP Checklist.

\begin{tabular}{|c|c|c|c|c|}
\hline \multicolumn{5}{|c|}{ DISASP Checklist } \\
\hline \multicolumn{5}{|c|}{ Axis I - Rational Use of Natural Resources and Public Goods } \\
\hline No. & Question & 0 & 12 & $\begin{array}{l}\text { NA - Not } \\
\text { applicable. }\end{array}$ \\
\hline $\mathrm{I} .1$ & $\begin{array}{l}\text { Does the autarky identify targets for reducing the supply of paper } \\
\text { per capita in sectors? }\end{array}$ & $\mathbf{X}$ & & \\
\hline 1.2 & $\begin{array}{l}\text { Does the autarky have goals to increase consumption of recycled } \\
\text { and non-chlorinated paper? }\end{array}$ & $\mathbf{X}$ & & \\
\hline 1.3 & $\begin{array}{l}\text { Does the autarky collect and track the consumption of paper used } \\
\text { for printing and copying, as well as printers that need maintenance } \\
\text { or replacement? }\end{array}$ & $\mathbf{X}$ & & \\
\hline 1.4 & Does the autarky make notepads with paper used on one side only? & $\mathbf{X}$ & & \\
\hline 1.5 & Does the autarky adopt a printing islands model? & $\mathbf{X}$ & & \\
\hline 1.6 & $\begin{array}{l}\text { Does the autarky adopt the guidelines proposed by the PROCEL } \\
\text { program and implement changes suggested by the diagnosis for } \\
\text { land certification, when relevant? }\end{array}$ & $\mathbf{X}$ & & \\
\hline 1.7 & $\begin{array}{l}\text { Has the autarky conducted a study of electrical installations to } \\
\text { diagnose actual losses? }\end{array}$ & $\mathbf{X}$ & & \\
\hline 1.8 & $\begin{array}{c}\text { Does the autarky's electrical installation comply with the norms and } \\
\text { standards required by legislation and ABNT? }\end{array}$ & & $\mathbf{X}$ & \\
\hline 1.9 & $\begin{array}{l}\text { Has the autarky conducted a feasibility study of using solar energy } \\
\text { in the building? }\end{array}$ & $\mathbf{X}$ & & \\
\hline 1.10 & $\begin{array}{c}\text { Does the autarky have a high-efficiency, low-environmental-impact } \\
\text { lighting system, with presence sensors in the appropriate } \\
\text { environments? }\end{array}$ & $\mathbf{X}$ & & \\
\hline $\mathrm{I} .11$ & Are the autarky's light switches individualized by work environment? & & $\mathbf{X}$ & \\
\hline $\mathrm{I} .12$ & $\begin{array}{l}\text { Is there an efficient air conditioning system in the autarky building, } \\
\text { with a scheduled opening time? }\end{array}$ & $\mathbf{X}$ & & \\
\hline $\mathrm{I} .13$ & $\begin{array}{l}\text { Does the autarky encourage lights and monitors to remain off during } \\
\text { lunchtime? }\end{array}$ & $\mathbf{X}$ & & \\
\hline $\mathrm{I} .14$ & $\begin{array}{l}\text { Does the autarky encourage use of the natural conditions of the } \\
\text { work environment - ventilation, sunlight? }\end{array}$ & $\mathbf{X}$ & & \\
\hline I.15 & $\begin{array}{l}\text { Does the autarky encourage the use of cups made from materials } \\
\text { that are conducive to reuse? }\end{array}$ & $\mathbf{X}$ & & \\
\hline $\mathrm{I} .16$ & $\begin{array}{l}\text { Does the autarky have targets for reducing the availability of } \\
\text { disposable cups? }\end{array}$ & $\mathbf{X}$ & & \\
\hline I.17 & Does the autarky diagnose water demand and use? & & $\mathbf{X}$ & \\
\hline I.18 & $\begin{array}{l}\text { Does the autarky routinely perform inspections of the building's } \\
\text { hydro-sanitary facilities to detect leaks and improper use of available } \\
\text { resources? }\end{array}$ & & $\mathbf{x}$ & \\
\hline I.19 & $\begin{array}{l}\text { Does the autarky's sanitary installation satisfy the norms and } \\
\text { standards required by legislation, as well as the criteria of } \\
\text { sustainability? }\end{array}$ & & $\mathbf{x}$ & \\
\hline 1.20 & $\begin{array}{l}\text { Has the autarky already replaced discharge valves with efficient } \\
\text { systems? }\end{array}$ & & $\mathbf{X}$ & \\
\hline 1.21 & $\begin{array}{l}\text { Has the autarky optimized the flow rate of lavatory faucets by } \\
\text { installing flow reducers or an alternative solution? }\end{array}$ & & $\mathbf{X}$ & \\
\hline 1.22 & $\begin{array}{l}\text { Does the autarky control the consumption of water and electricity in } \\
\qquad \text { an individualized way? }\end{array}$ & & & $\mathbf{X}$ \\
\hline 1.23 & $\begin{array}{l}\text { Does the autarky have an implanted system for use of rainwater and } \\
\text { reuse of gray water? }\end{array}$ & & $\mathbf{X}$ & \\
\hline 1.24 & Does the autarky run rational fuel use campaigns? & $\mathbf{X}$ & & \\
\hline 1.25 & Does the autarky run rational phone use campaigns? & $\mathbf{X}$ & & \\
\hline
\end{tabular}


Appendix A. Continued...

\begin{tabular}{|c|c|c|c|}
\hline \multicolumn{4}{|c|}{ DISASP Checklist } \\
\hline 1.26 & Does the autarky use alternative fuels in the vehicle fleet? & $\mathbf{X}$ & \\
\hline 1.27 & $\begin{array}{l}\text { Does the autarky have defined processes for preventive } \\
\text { maintenance of furniture, real estate, vehicles, and equipment? }\end{array}$ & $\mathbf{X}$ & \\
\hline 1.28 & $\begin{array}{l}\text { Does the autarky identify and monitor department-specific goals and } \\
\text { indicators of efficiency in the maintenance area? }\end{array}$ & $\mathbf{x}$ & \\
\hline \multicolumn{4}{|c|}{ Axis II - Adequate Management of Generated Waste } \\
\hline No. & Question & 0112 & NA \\
\hline II.1 & $\begin{array}{c}\text { Does the autarky have a Solid Waste Management Plan included as } \\
\text { part of the selective solidary collection? }\end{array}$ & $\mathbf{X}$ & \\
\hline II.2 & $\begin{array}{c}\text { Does the autarky have a participatory diagnosis of the current solid } \\
\text { waste management situation? }\end{array}$ & $\mathbf{X}$ & \\
\hline II.3 & Does the autarky train cleaning staff quarterly? & $\mathbf{X}$ & \\
\hline II.4 & $\begin{array}{c}\text { Are signs and adhesives posted to facilitate segregation of } \\
\text { materials? }\end{array}$ & $\mathbf{X}$ & \\
\hline II.5 & $\begin{array}{l}\text { Does the autarky dispose of tailings in an environmentally correct } \\
\text { way? }\end{array}$ & $\mathbf{x}$ & $\mathbf{X}$ \\
\hline II.6 & $\begin{array}{c}\text { Has the autarky already created a selective collection sector } \\
\text { commission with one representative per unit (involving other } \\
\text { institutions located in the same building or condominium, when } \\
\text { applicable)? }\end{array}$ & $\mathbf{X}$ & \\
\hline II.7 & $\begin{array}{c}\text { Does the autarky donate recyclable materials to associations and } \\
\text { cooperatives of recyclable waste pickers? }\end{array}$ & $\mathbf{X}$ & \\
\hline II.8 & Does the autarky prevent and reduce waste generation? & $\mathbf{X}$ & \\
\hline 11.9 & $\begin{array}{c}\text { Does the autarky have established practices and habits for } \\
\text { sustainable consumption? }\end{array}$ & $\mathbf{x}$ & \\
\hline II.10 & Does the autarky increase recycling and reuse of solid waste? & $\mathbf{X}$ & \\
\hline II.11 & $\begin{array}{c}\text { Does the autarky collect, handle, store, transport, and dispose of } \\
\text { waste properly, with minimal risks to humans and the environment, } \\
\text { including hazardous waste such as lightbulbs and electrical and } \\
\text { electronic equipment? }\end{array}$ & $\mathbf{x}$ & $\mathbf{X}$ \\
\hline \multicolumn{4}{|c|}{ Axis III - Quality of Life in the Work Environment } \\
\hline No. & Question & $\begin{array}{lll}0 & 1 & 2\end{array}$ & NA \\
\hline III.1 & $\begin{array}{l}\text { Does the autarky encourage employees to engage in physical } \\
\text { activities? }\end{array}$ & $\mathbf{X}$ & \\
\hline III.2 & $\begin{array}{l}\text { Does the autarky stimulate employees' physical and social well- } \\
\text { being through training and community activities, such as walking } \\
\text { and foot racing? }\end{array}$ & $\mathbf{X}$ & \\
\hline III.3 & $\begin{array}{l}\text { Does the autarky add work gymnastics to the institutional routine to } \\
\text { reduce employees' tension on their career path, increasing the } \\
\text { motivation and quality of the professional environment? }\end{array}$ & $\mathbf{x}$ & \\
\hline III.4 & Does the autarky conduct specific bicycle promotion events? & $\mathbf{X}$ & \\
\hline III.5 & Does the autarky promote the periodic vaccination of employees? & $\mathbf{X}$ & \\
\hline III.6 & Has the autarky developed a Retirement Preparation Plan? & $\mathbf{X}$ & \\
\hline III.7 & Does the autarky promote events focused on women's health? & $\mathbf{X}$ & \\
\hline III.8 & $\begin{array}{l}\text { Does the autarky verify that the air quality and noise level of the } \\
\text { working environment meet the requirements of legislation? }\end{array}$ & $x$ & \\
\hline III.9 & $\begin{array}{l}\text { Does the autarky have an environmental risk prevention program in } \\
\text { place? }\end{array}$ & $X$ & \\
\hline III.10 & $\begin{array}{l}\text { Does the autarky meet the health and safety standards for internal } \\
\text { and external employees? }\end{array}$ & $x$ & $\mathrm{X}$ \\
\hline III.11 & $\begin{array}{l}\text { Does the autarky have an Internal Commission for the Prevention of } \\
\text { Accidents? }\end{array}$ & $x$ & \\
\hline
\end{tabular}




\section{DISASP Checklist}

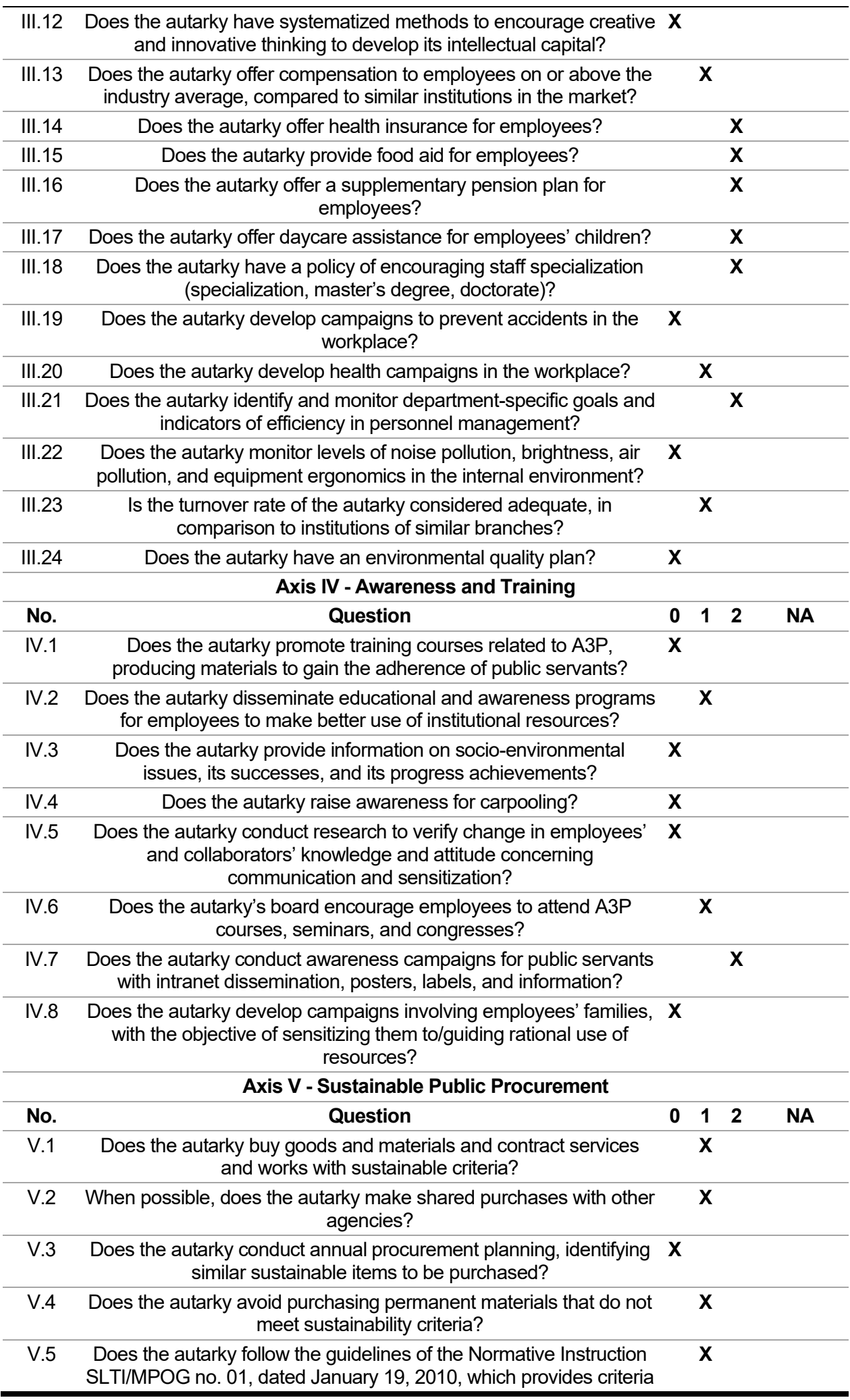


Appendix A. Continued...

\section{DISASP Checklist}

for environmental sustainability in acquisition of goods, contracting services, or works?

V.6 Does the autarky follow the guidelines of Administrative Rule no. 02 of the MPOG, dated March 16, 2010, and Normative Instruction no.

01 of the MPOG, dated January 19, 2010, regarding Information Technology - Green IT?

V.7 Does the autarky have a code of conduct for suppliers relating to $\mathbf{X}$ environmental issues?

$\begin{array}{crc}\text { V.8 } & \text { Does the autarky use electronic purchasing processes or similar? } & \mathbf{X} \\ \text { V.9 } & \text { Does the autarky require supplies to provide any kind of } & \mathbf{X}\end{array}$ environmental certification?

V.10 Does the autarky prioritize hiring suppliers with environmental $\quad \mathbf{X}$ programs/projects?

V.11 Are conditions and quality terms applied when the purchase of $\quad \mathbf{X}$ inputs and equipment takes place in the autarky?

V.12 Does the autarky have defined processes to verify the quality of the $\mathbf{X}$ products/services offered/contracted?

V.13 Does the autarky invest in research and development of less- $\quad \mathbf{X}$ polluting substitutes?

V.14 When choosing the company to maintain the vehicle fleet, does the $\mathbf{X}$ autarky prioritize hiring suppliers with environmental programs/projects?

V.15 When choosing the company to maintains the properties, does the $\mathbf{X}$ autarky prioritize contracting suppliers with environmental programs/projects?

\begin{tabular}{|c|c|c|c|c|}
\hline \multicolumn{5}{|c|}{ Axis VI - Sustainable Construction } \\
\hline No. & Question & 0 & 12 & NA \\
\hline VI.1 & $\begin{array}{l}\text { Does the autarky plan works each year with guidelines for } \\
\text { sustainable construction? }\end{array}$ & $\mathbf{x}$ & & \\
\hline Vl.2 & $\begin{array}{l}\text { Does the autarky seek to improve preventive building maintenance } \\
\text { routines to reduce costs of corrective land maintenance? }\end{array}$ & & $\mathbf{x}$ & \\
\hline VI.3 & $\begin{array}{l}\text { Does the autarky have covered bicycle racks and support } \\
\text { infrastructure, such as locker rooms and others? }\end{array}$ & & $\mathbf{x}$ & \\
\hline VI.4 & $\begin{array}{l}\text { In construction and renovation, does the autarky seek to identify and } \\
\text { use durable, certified, and sustainable materials, preferably recycled } \\
\text { and derived from renewable natural resources? }\end{array}$ & $\mathbf{X}$ & & \\
\hline VI.5 & $\begin{array}{l}\text { Does the autarky seek to reduce waste of materials in building } \\
\text { maintenance, renovations, and works? }\end{array}$ & & $\mathbf{x}$ & \\
\hline VI.6 & $\begin{array}{l}\text { Does the autarky allocate reusable and recyclable waste from works } \\
\text { to associations and cooperatives of recyclable materials? }\end{array}$ & $\mathbf{X}$ & & \\
\hline VI.7 & Does the autarky correctly dispose of hazardous waste? & & $\mathbf{X}$ & \\
\hline VI.8 & $\begin{array}{l}\text { Has the autarky already verified the feasibility of works for retention } \\
\text { and infiltration of rainwater in soil to avoid runoff and flooding in } \\
\text { areas near the building? }\end{array}$ & $\mathbf{x}$ & & \\
\hline VI.9 & $\begin{array}{l}\text { Does the autarky have adequate spaces to accommodate } \\
\text { accessibility issues? }\end{array}$ & & $\mathbf{X}$ & \\
\hline VI.10 & $\begin{array}{l}\text { Are inadequate products/materials found during building } \\
\text { maintenance collected in suitable containers? }\end{array}$ & & $\mathbf{X}$ & \\
\hline VI.11 & $\begin{array}{l}\text { Does the autarky have defined processes to guide recycling or } \\
\text { storage of discarded equipment (computer, furniture, chairs, etc.) on } \\
\text { the premises? }\end{array}$ & & $\mathbf{x}$ & \\
\hline \multicolumn{5}{|c|}{ Axis VII - Social and Environmental Responsibility } \\
\hline No. & Question & $\mathbf{0}$ & 12 & NA \\
\hline
\end{tabular}


Appendix A. Continued...

\section{DISASP Checklist}

\begin{tabular}{|c|c|c|c|}
\hline VII.1 & $\begin{array}{l}\text { Does the autarky identify issues and address the social and } \\
\text { environmental impacts of its products and processes and the } \\
\text { facilities on which it has influence? }\end{array}$ & $\mathbf{X}$ & \\
\hline VII.2 & $\begin{array}{c}\text { Does the autarky promote actions involving preservation of the } \\
\text { ecosystem, conservation of non-renewable resources, and } \\
\text { minimization renewable resource use? }\end{array}$ & $\mathbf{X}$ & \\
\hline VII.3 & $\begin{array}{l}\text { Are autarky workers aware of and involved in issues related to } \\
\text { environmental preservation and social development? }\end{array}$ & $\mathbf{X}$ & \\
\hline VII.4 & $\begin{array}{l}\text { Does the autarky have systematic processes to include socio- } \\
\text { environmental preservation actions in its community projects? }\end{array}$ & $\mathbf{X}$ & \\
\hline VII.5 & Does the autarky invest in environment-related media campaigns? & & $\mathbf{X}$ \\
\hline VII.6 & $\begin{array}{c}\text { Does the autarky invest in/provide sponsorships associated with } \\
\text { environmental preservation issues? }\end{array}$ & $\mathbf{X}$ & \\
\hline VII.7 & $\begin{array}{l}\text { Does the autarky have a communication policy regarding its social } \\
\text { and environmental responsibility? }\end{array}$ & $\mathbf{x}$ & \\
\hline VII.8 & $\begin{array}{l}\text { In advertising, does the autarky use a slogan with an appeal to } \\
\text { preserve the environment? }\end{array}$ & $\mathbf{x}$ & \\
\hline VII.9 & $\begin{array}{l}\text { Does the autarky support and encourage internal initiatives offering } \\
\text { solutions to minimize its environmental effects? }\end{array}$ & $\mathbf{x}$ & \\
\hline VII.10 & $\begin{array}{l}\text { In the last two years, has the autarky won any award/recognition for } \\
\text { voluntary services, preservation of the environment, citizen } \\
\text { institution, etc.? }\end{array}$ & $\mathbf{x}$ & \\
\hline
\end{tabular}

VII.11 Does the autarky have defined processes and indicators to measure $\mathbf{X}$ the adverse social and environmental impacts of its products, processes, and facilities?

\begin{tabular}{|c|c|c|c|c|}
\hline \multicolumn{5}{|c|}{ Axis VIII - Institutional Management } \\
\hline No. & Question & 0 & 12 & NA \\
\hline VIII.1 & $\begin{array}{c}\text { Does the autarky have assets in use in the processes of protection, } \\
\text { control, preservation, and environmental recovery? }\end{array}$ & & $\mathbf{X}$ & \\
\hline VIII.2 & $\begin{array}{l}\text { Does the autarky have environmental liabilities related to loans and } \\
\text { financing in environmental management? (inverse) }\end{array}$ & $\mathbf{X}$ & & \\
\hline VIII.3 & $\begin{array}{l}\text { In the last two years, has the autarky been assessed or fined for } \\
\text { environmental reasons? (inverse) }\end{array}$ & & $\mathbf{X}$ & $\mathbf{X}$ \\
\hline VIII.4 & $\begin{array}{l}\text { Does the autarky participate in environmental preservation } \\
\text { campaigns? }\end{array}$ & & $\mathbf{X}$ & \\
\hline VIII.5 & Does the autarky have an environmental management system? & $\mathbf{X}$ & & \\
\hline VIII.6 & $\begin{array}{l}\text { Does the autarky have defined processes that enable systematic } \\
\text { financial investments in environmental protection? }\end{array}$ & $\mathbf{X}$ & & \\
\hline VIII.7 & $\begin{array}{c}\text { Does the autarky identify and monitor goals and indicators of } \\
\text { environmental efficiency? }\end{array}$ & $\mathbf{X}$ & & \\
\hline VIII.8 & $\begin{array}{c}\text { Does the autarky's planning prioritize investments/projects in the } \\
\text { area of environmental management? }\end{array}$ & & $\mathbf{X}$ & $\mathbf{X}$ \\
\hline VIII.9 & $\begin{array}{c}\text { Does the autarky have best-practice processes in the area of } \\
\text { environmental management? }\end{array}$ & $\mathbf{X}$ & & \\
\hline VIII.10 & $\begin{array}{l}\text { Does the autarky invest in research and development of } \\
\text { environmental technologies? }\end{array}$ & & $\mathbf{X}$ & $\mathbf{X}$ \\
\hline VIII.11 & $\begin{array}{l}\text { Does the autarky have salaries and charges from environmental } \\
\text { experts? }\end{array}$ & $x$ & & \\
\hline VIII.12 & $\begin{array}{l}\text { Is leadership in the autarky exercised such that decisions can be } \\
\text { made, communicated, and implemented to meet stakeholder needs } \\
\text { in a harmonious and balanced way? }\end{array}$ & & $x$ & \\
\hline VIII.13 & $\begin{array}{c}\text { Does the autarky's senior management interact with all } \\
\text { stakeholders, demonstrating commitment and seeking opportunities } \\
\text { for the organization? }\end{array}$ & & $X$ & \\
\hline
\end{tabular}


Appendix A. Continued...

\section{DISASP Checklist}

\begin{tabular}{|c|c|c|}
\hline VIII.14 & $\begin{array}{l}\text { Does the autarky have production processes certified by any } \\
\text { agency? }\end{array}$ & $\mathbf{x}$ \\
\hline VIII.15 & $\begin{array}{l}\text { Does the autarky monitor indicators of carbon emissions as a result } \\
\text { of its production processes? }\end{array}$ & $\mathbf{x}$ \\
\hline VIII.16 & Does the autarky have carbon offset programs? & $\mathbf{x}$ \\
\hline
\end{tabular}

